\title{
Analisis Regresi Pada Banyaknya Obyek Penerimaan Pajak Kendaraan Bermotor
}

Saiful Marom

Program Studi Tadris Matematika FTIK IAIN Salatiga, saifulmarom2704@gmail.com

\begin{abstract}
ABSTRAK, Tujuan dari penelitian ini adalah mengetahui pengaruh banyaknya keluarga sejahtera dan banyaknya pencurian kendaraan bermotor terhadap banyaknya obyek penerimaan pajak kendaraan bermotor di Provinsi jawa Tengah. Variabel Penelitian ini terdiri dari variabel bebas yaitu banyaknya banyaknya pencurian kendaraan bermotor dan tingkat kesejahteraan masyarakat serta Variabel terikatnya adalah banyaknya objek pajak yang membayar pajak kendaraan bermotor. Dari hasil penelitian diperoleh persamaan regresi ganda $Y=$ $73,858+0,769 X_{1}-0,0982 X_{2}$ dengan besar pengaruh banyaknya keluarga sejahtera dan banyaknya pencurian kendaraan bermotor terhadap banyaknya objek penerimaan pajak kendaraan bermotor sebesar 59,6\%
\end{abstract}

Kata Kunci: Persamaan regresi, pajak kendaraan bermotor, keluarga sejahtera.

\section{PENDAHULUAN}

Statistika merupakan ilmu yang mempelajari tentang pengumpulan, pengolahan, penyajian dan analisa data serta penarikan kesimpulan secara umum berdasarkan analisa yang dilakukan. Dinas Pendapatan dan Pengelolaan Aset Daerah (DPPAD) merupakan instansi yang mengelola pendapatan dan aset daerah yang kemudian akan melaporkannya kepemerintah pusat. Dinas Pendapatan dan Pengelolaan Aset Daerah (DPPAD) Provinsi Jawa tengah memiliki manajemen yang sudah diatur dalam undang-undang. Salah satu bidang yang ada di Dinas Pendapatan dan Pengelolaan Aset Daerah (DPPAD) Provinsi Jawa tengah adalah bidang pajak, yang diantaranya bertugas untuk menangani masalah pajak kendaraan bermotor di Provinsi Jawa tengah.

Dalam kajiannya Pratowo (2001) untuk meningkatkan kesadaran obyek pajak untuk membayar pajak kendaraan bermotor perlu diketahui faktor-faktor yang mempengaruhi banyaknya obyek pajak yang membayar pajak. Dari data yang telah dikumpulkan dapat digunakan konsep statistik berkaitan dengan analisis regresi mengenai faktor-faktor yang mempengaruhi banyaknya obyek penerimaan pajak kendaraan bermotor.
Menurut Arsyad (1992), sampai saat ini potensi sektor pajak merupakan sektor dominan yang menunjang pendapatan di Provinsi Jawa tengah. Banyaknya obyak penerimaan pajak kendaraan bermotor di kabupaten dan kota di daerah Provinsi Jawa tengah berbeda-beda diakibatkan beberapa faktor. Menurut Ndakularak (2008), faktor yang dapat mempengaruhi banyaknya obyak penerimaan pajak kendaraan bermotor adalah banyaknya diantaranya adalah keluarga sejahtera, banyaknya pencurian kendaraan bermotor di tiap-tiap kabupaten dan kota di Provinsi Jawa tengah serta yang lainnya.

Untuk mengetahui adanya pengaruh antara banyaknya keluarga sejahtera dan banyaknya pencurian kendaraan bermotor terhadap banyaknya obyek penerimaan pajak kendaraan bermotor di Provinsi Jawa tengah maka diperlukan suatu kajian. Penulis tertarik untuk meneliti tentang pengaruh banyaknya keluarga sejahtera dan banyaknya pencurian kendaraan bermotor terhadap banyaknya obyek penerimaan pajak kendaraan bermotor di Provinsi Jawa tengah tahun 2017.

\section{TINJAUANPUSTAKA}

Berdasarkan data yang ada di Dinas Pendapatan Dan Pengelolaan Aset Daerah Provinsi Jawa Tengah, Penulis ingin mengetahui besarnya pengaruh banyaknya keluarga sejahtera dan banyaknya pencurian kendaraan bermotor terhadap banyaknya obyek penerimaan pajak kendaraan bermotor di Provinsi Jawa Tengah tahun 2017 dengan menggunakan analisis regresi linear yaitu analisis regresi sederhana dan analisis regresi ganda. Dalam tulisan ini untuk mengetahui pengaruh antara benyaknya keluarga sejahtera terhadap banyaknya obyek penerimaan pajak kendaraan bermotor penulis menggunakan analisis regresi sederhana karena terdiri dari satu variabel bebas yaitu banyaknya keluarga sejahtera $\left(X_{1}\right)$, banyaknya pencurian kendaraan bermotor $\left(X_{2}\right)$ dan satu variabel terikat yaitu 
banyaknya obyek penerimaan pajak kendaraan bermotor $(Y)$, untuk mengetahui pengaruh antara banyaknya pencurian kendaraan bermotor terhadap banyaknya obyek penerimaan pajak kendaraan bermotor penulis menggunakan analisis regresi sederhana karena terdiri dari satu variabel bebas yaitu banyaknya pencurian kendaraan bermotor $\left(X_{2}\right)$ dan satu variabel terikat yaitu banyaknya obyek penerimaan pajak kendaraan bermotor $(Y)$. Dan untuk mengetahui pengaruh banyaknya keluarga sejahtera dan banyaknya pencurian kendaraan bermotor terhadap banyaknya obyek penerimaan pajak kendaraan bermotor penulis menggunakan analisis regresi berganda.

karena terdiri dari dua variabel bebas yaitu banyaknya keluarga sejahtera $\left(X_{1}\right)$, banyaknya pencurian kendaraan bermotor $\left(X_{2}\right)$ dan satu variabel terikat yaitu banyaknya obyek penerimaan pajak kendaraan bermotor $(Y)$.

\section{a. Regresi Linier}

Analisis regresi merupakan suatu kajian mengenai ketergantungan satu variabel, variabel tak bebas, pada satu atau lebih variabel lain, variabel yang menjelaskan (explanatory variables), dengan maksud menaksir atau memprediksi dari nilai rata-rata sampel atau rata-rata (populasi) variabel tak bebas, dipandang dari segi nilai yang diketahui atau tetap (dalam pengambilan sampel berulang) variabel yang menjelaskan atau yang belakangan (Gujarati,1978).

Persamaan regresi linear terdiri dari dua model yaitu regresi linear sederhana dan regresi linear ganda. Regresi linear sederhana hanya mempunyai satu variabel bebas (independent) yaitu $(X)$ dan satu variabel terikat (dependent) yaitu $(Y)$.

Linear Regression digunakan untuk melakukan pengujian hubungan antara sebuah variabel dependent (tergantung) dengan satu atau beberapa variabel independent (bebas) yang ditampilkan dalam bentuk persamaan regresi. Jika variabel dependent dihubungkan dengan satu variabel independent saja, persamaan regresi yang dihasilkan adalah regresi linear sederhana (linear regression). Jika variabel independent-nya lebih dari satu, maka persamaan regresinya adalah persamaan regresi linear berganda (multiple linear regression).

\section{Regresi Linier Sederhana}

\section{Model Regresi Linier Sederhana}

Dalam statistik pasangan pengamatan yang melibatkan dua variabel atau lebih dinyatakan dengan simbol $(X, Y)$. Hubungan antara dua variabel pada persamaan linier jika digambarkan secara grafis (scatter diagram), semua nilai $X$ dan akan berada dalam suatu garis lurus. Dalam ilmu ekonomi, garis tersebut disebut garis regresi.

Untuk dua variabel, hubungan liniernya dapat dinyatakan dalam bentuk persamaan linier yaitu :

$$
\hat{\mathrm{Y}}=\mathrm{a}+\mathrm{bX}
$$

Dengan :

$\mathrm{X}$ : Variabel bebas

$\hat{\mathrm{Y}}$ : Variabel bergantung

a,b : Bilangan konstan

(Konstanta)

$Y$ merupakan variabel tak bebas atau disebut juga variabel bergantung (dependent variable) yaitu variabel yang dipengaruhi. Sedangkan $X$ merupakan variabel bebas atau disebut juga variabel tak bergatung (independent variable) yaitu variabel yang mempengaruhi.

Karena populasi jarang diamati langsung, maka digunakan persamaan regresi linier sederhana. Sampel sebagai penduga persamaan regresi linier sederhana populasi.

\section{Uji Keberartian Regresi}

Selain menguji kelinearan dankeberartian dari model dilakukan juga uji keberartian koefisien regresi dengan menggunakan statistik t student sebagai pengujinya. Hipotesis yang digunakan adalah sebagai berikut:

$\mathrm{H}_{0}$ : koefisien regresi tidak signifikan

$\mathrm{H}_{1}$ : koefisien regresi signifikan

Nilai $\mathrm{t}$ hitung dapat dilihat dari tabel Coefficients pada output SPSS. Tolak $\mathrm{H}_{0}$ jika $-\mathrm{t}$ tabel $<\mathrm{t}$ hitung $<\mathrm{t}$ tabel. Dengan melihat tabel distribusi $\mathrm{t}$ untuk taraf signifikan $(\alpha)$ tertentu dan derajat kebebasan $(d k)=n-2$ akan diperoleh nilai t tabel. 


\section{Regresi Linier Berganda}

\section{Model Regresi Linier Berganda}

Persamaan regresi berganda mengandung makna bahwa suatu persamaan regresi terdapat satu variabel terikat dan lebih dari satu variabel bebas. Dalam kasus ekonomi dan bisnis sering kali dijumpai perubahan suatu variabel disebabkan oleh variabel lain.

Banyak data pengamatan yang terjadi sebagai akibat lebih dari dua variabel. Pengujian hipotesis dalam penelitian ini menggunakan statistik parametrik, karena data variabel berbentuk data interval. Sedangkan analisis yang digunakan dalam penelitian ini adalah analisis regresi dan korelasi.

\section{METODOLOGI}

Jenis data yang digunakan pada penelitian ini adalah dengan menggunakan data sekunder, yakni sumber data yang didapatkan dari peneliti secara tidak langsung melalui media perantara. Selanjutnya pada penelitian ini akan digunakan satu variabel terikat dan dua variabel bebas. Variabel terikat yang digunakan pada penelitian ini adalah Banyaknya objek pajak yang membayar kendaraan bermotor serta Variabel bebas pada penelitian ini adalah Tingkat kesejahteraan masyarakat di provinsi jawa tengah serta banyaknya pencurian kendaraan bermotor.

Metode analisis yang digunakan adalah dengan menggunakan analisis regresi linear berganda dan uji asumsi klasik yang diantaranya adalah uji normalitas dara, uji multikolinearitas, uji autokorelas serta uji heterokedastisitas.

\section{PEMBAHASAN}

\section{Uji Normalitas Data}

Berdasarkan teori statistika model linier hanya variabel dependent $\mathrm{Y}$ yang mempunyai distribusi diuji normalitasnya , sedangkan variabel independent $X_{1}$ dan $X_{2}$ diasumsikan bukan fungsi distribusi. Jadi tidak perlu diuji normalitasnya (Sukestiyarno,2006:12).
Analisis data hasil Output :

Uji normalitas data digunakan hipotesis sebagai berikut :

\section{NPar Tests}

One-Sample Kolmogorov-Smirnov Test

\begin{tabular}{|ll|r|}
\hline & & \multicolumn{1}{|c|}{$\mathrm{Y}$} \\
\hline $\mathrm{N}$ & & 35 \\
Normal Parameters a,b & Mean & 142988.8 \\
& Std. Deviation & 102988.3 \\
Most Extreme & Absolute & .194 \\
Differences & Positive & .194 \\
& Negative & -.168 \\
Kolmogorov-Smirnov Z & & 1.150 \\
Asymp. Sig. (2-tailed) & & .142 \\
\hline
\end{tabular}

a. Test distribution is Normal.

b. Calculated from data.

$\mathrm{H}_{o}$ : Data berdistribusi normal

$\mathrm{H}_{1}$ : Data tidak berdistribusi normal

Kriteria penerimaan $\mathrm{H}_{o}$

$\mathrm{H}_{o}$ diterima jika nilai sig (2-tailed) $>5 \%$.

Dari tabel diperoleh nilai sig $=0,142=$ $14,2 \%>5 \%$, maka $\mathrm{H}_{o} \quad$ diterima. Artinya

data $Y$ (banyaknya obyek penrimaan pajak kendaraan bermotor) berdistribusi normal.

\section{Uji Autokorelasi}

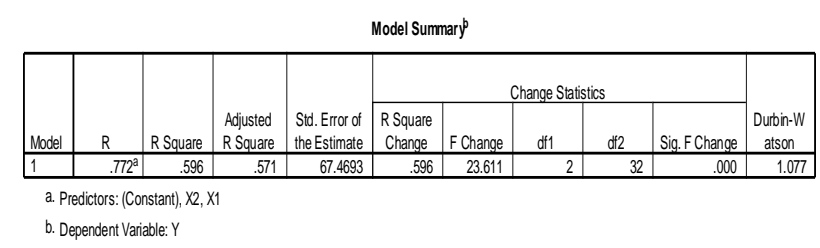

Dari tabel Model Summary diatas diperoleh nilai Durbin Watson yaitu 1,077. Nilai tersebut terletak didalam selang [ -2, 2 ], maka tidak terjadi autokorelasi. Artinya tidak ada korelasi antara error satu dengan error yang lain.

\section{Uji Multikolinearitas}

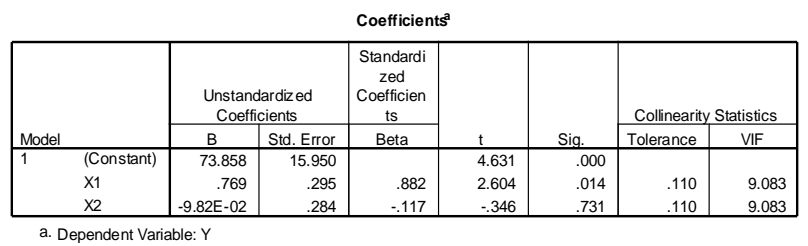

Dari tabel Coefficients diperoleh nilai tolerance $0,110<1$ dan nilai VIF 9,083 < 10. Sehingga tidak terjadi multikolinearitas. Artinya tidak terjadi korelasi yang tinggi antara variabel bebas. 


\section{Uji Heterokedastisitas}

Scatterplot

Dependent Variable: $Y$

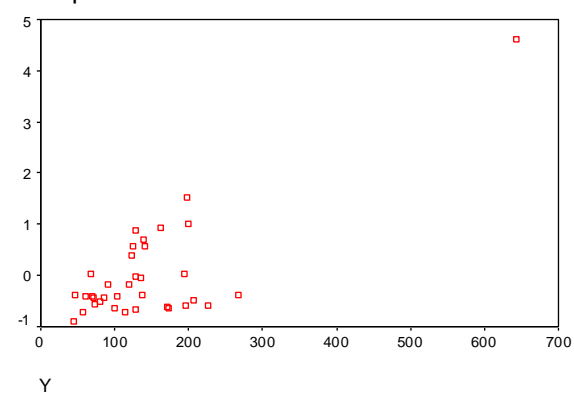

Pada diagram Scatterplot dapat dilihat bahwa nilai error cukup menyebar disekitar nol, jadi tidak terjadi heterokedastisitas. Artinya error memiliki varians konstan.

\section{Persamaan Regresi Linear Ganda}

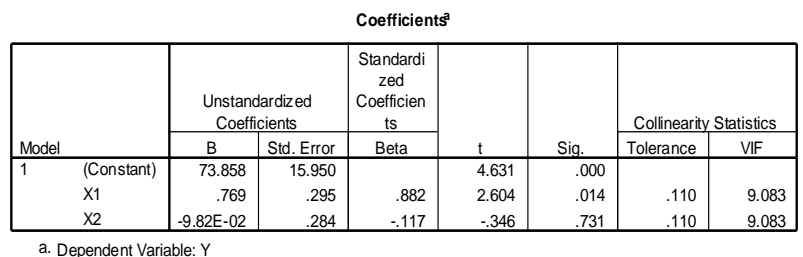

Dari tabel Coefficients diperoleh persamaan regresi ganda sebagai barikut :

$$
Y=73,858+0,769 X_{1}-0,0982 X_{2}
$$

Berdasarkan persamaan sebelumnya maka dapat disimpulkan bahwa jika semakin banyak keluarga sejahtera maka semakin banyak obyek penerimaan pajak kendaraan bermotor dan jika semakin banyak pencurian kendaraan bermotor maka semakin sedikit obyek penerimaan pajak kendaraan bermotor.

Dari table Model Summary diperoleh nilai R Square $=0,596=59,6 \%$. Artinya bahwa $X_{1}$ dan $X_{2}$ memberikan pengaruh terhadap $Y$ sebesar $59,6 \%$ sedangkan $40,6 \%$ dipengaruhi faktor lain.

\section{KESIMPULAN}

Berdasarkan pembahasan dan analisa di atas dapat diambil simpulan bahwa Persamaan regresi antara banyaknya keluarga sejahtera $\left(X_{1}\right)$ dan banyaknya pencurian kendaraan bermotor $\left(X_{2}\right)$ terhadap banyaknya obyek penerimaan pajak kendaraan bermotor $(Y)$ adalah $\quad Y=73,858+0,769 X_{1}-0,0982 X_{2}$ dengan besar pengaruh banyaknya keluarga sejahtera dan banyaknya pencurian kendaraan bermotor terhadap banyaknya obyek penerimaan pajak kendaraan bermotor sebesar $59,6 \%$

\section{DAFTAR PUSTAKA}

[1] Arsyad, L, 1992. "Ekonomi Pembangunan Edisi Kedua”. Yogyakarta : Bagian Penerbitan Sekolah Tinggi Ilmu Ekonomi :YKPN.

[2] Gujarat, D dan Zain S, 1978. “Ekonometrika Dasar”.Jakarta :Erlangga.

[3] Ndakularak, Erwin, 2001. "Analsis Faktor-faktor yang Mempengaruhi Kesejahteraan Masyarakat Kabupaten/Kota di Provinsi Bali”. Jurnal Studi : Universitas Udayana.

[4] Pratowo, 2001. "Analsis Faktpr-faktor yang berpengaruh terhadap Indeks Pembangunan Manusia se Kabupaten/Kota di Jawa Tengah. Jurnal Studi Ekonomi Indonesia.

[5] Sudjana, 2003. "Metode Statistika". Bandung:Tarsito.

[6] Sukestiyarno, 2006. "Instrumen dan Analisis Data Penelitian". Semarang:UNNES. 